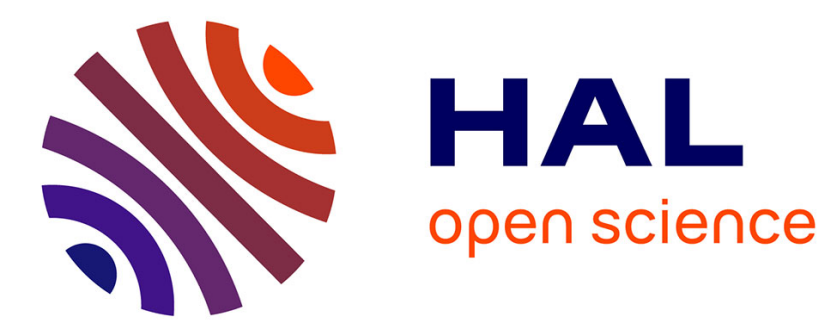

\title{
Inequality in Emerging Countries
}

Nathalie Chusseau, Joël Hellier

\section{To cite this version:}

Nathalie Chusseau, Joël Hellier. Inequality in Emerging Countries. 2012. hal-00993411

\section{HAL Id: hal-00993411 \\ https://hal.univ-lille.fr/hal-00993411}

Preprint submitted on 20 May 2014

HAL is a multi-disciplinary open access archive for the deposit and dissemination of scientific research documents, whether they are published or not. The documents may come from teaching and research institutions in France or abroad, or from public or private research centers.
L'archive ouverte pluridisciplinaire HAL, est destinée au dépôt et à la diffusion de documents scientifiques de niveau recherche, publiés ou non, émanant des établissements d'enseignement et de recherche français ou étrangers, des laboratoires publics ou privés. 


\section{Document de travail}

\section{- [2012-25] \\ "Inequality in Emerging Countries"}

Nathalie Chusseau and Joël Hellier

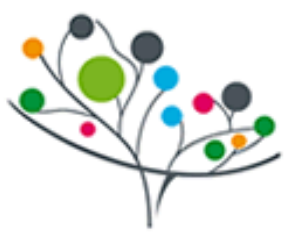

Université Lille Nord de France

Pole de Recherche

et dEnselgnement Superieur 


\title{
"Inequality in Emerging Countries"
}

\author{
Nathalie Chusseau and Joël Hellier
}

\section{Nathalie Chusseau}

PRES Université Lille Nord de France, Université Lille 1, Laboratoire EQUIPPE EA 4018, Villeneuve d'Ascq, France.

Nathalie.Chusseau@univ-lille1.fr

\section{Joël Hellier}

PRES Université Lille Nord de France, Université Lille 1, Laboratoire EQUIPPE EA 4018, Villeneuve d'Ascq, France

joel.hellier@wanadoo.fr LEMNA, Univ. of Nantes 


\title{
Inequality in Emerging Countries
}

\author{
Nathalie Chusseau \\ EQUIPPE, University of Lille 1 \\ Joël Hellier* \\ EQUIPPE, Univ. of Lille 1, and LEMNA, Univ. of Nantes
}

\begin{abstract}
We review the theoretical and empirical economic literature upon income inequality in emerging countries. We firstly describe the main observed developments and show that these are rather diverse across countries and developing regions. We subsequently expose the main theoretical mechanisms. We make a distinction between the traditional approaches (Kuznets, Lewis, Stolper-Samuelson) and the new explanations. In the latter, globalization and globalization-driven technological changes are at the core of the analyses. Both approaches bring out several opposite mechanisms. Finally, the empirical estimates display rather conflicting results. Most cross-country studies find a weak impact of globalization on income inequality. In contrast, several longitudinal studies concerning countries taken separately or small groups of countries reveal a positive correlation between openness and the relative demand for skill and inequality. These apparently conflicting findings reflect the opposite mechanisms linked to globalisation and the differences in countries' experiences.
\end{abstract}

Key words: Development, Emerging countries, Globalization, Inequality, Technology.

JEL Classification: E24, F43, O11, O15.

We wish to thank the French Research national Agency (ANR) for its financial support.

*Contact: joel.hellier@wanadoo.fr 


\section{Introduction}

In the last three decades, emerging countries have experienced a significant rise in growth, and thus in their real income per capita. After almost two centuries of 'great divergence' (Pomeranz, 2000; Prichett, 1997) characterised by growth rates significantly higher in the North (developed countries) than in the South (developing countries), this surge in growth within a majority of less developed countries could open a new era of 'great convergence' on the World stage. Nevertheless, this has not coincided with a decrease in within-country inequalities. The increase in income inequality in the North is now well documented (see Chusseau et al, 2008, for a review). In the South, the variations in within-country income inequality appear rather diverse (Wood, 1997).

Emerging East Asian countries experienced a decrease in inequality during the seventies and eighties (Krongkaew, 1994) followed by growing inequalities in the nineties and 2000s (Zin, 2005; Ortiz \& Cummins, 2011). However, Solt (2009) calculations provide a more ambiguous diagnosis. After a continuous increase in inequality in the 1990s, a majority of Latin American countries have experienced a decrease in inequality in the 2000s (Ortiz \& Cummins, 2011; Gasparini \& Lustig, 2011; Lustig \& al, 2011). Similarly, inequality rose in China from the eighties up to the mid-2000s, and it subsequently seems to have declined. In India, after a long period of stagnation from the 1960s up the mid-1990s, inequality seems to have slightly increased. Finally, if the general diagnosis is that of an increase in inequality within emerging countries over the last thirty years (Goldberg and Pavcnik, 2007), a turning point towards more equality could have occurred in the 2000s for a number of countries.

In developing countries, growth acceleration has been accompanied by a significant openness of their economies. The weights of trade and FDI inflows in GDP have substantially increased. Growth acceleration and increasing openness are the two sides of emerging countries' new model of development, and the positive impact of the latter on the former is now well documented (Crafts, 2004). Consequently, the recent economic literature dedicated to the explanation for inequality in the South has focused on the impacts of openness (Wood, 1997, O’Conner \& Lunati, 1999, Arbache, 2001, Cooper, 2002, and Rama, 2003, for early reviews; Anderson, 2005, and Goldberg \& Pavcnik, 2007 for recent surveys). Openness influences income distribution within developing countries through a number of channels. The traditional Stolper-Samuelson effect tends to lower inequality by reducing the skill premium. In contrast, transfers of more skill-intensive technologies from the North, the 
cornering of new skill-intensive goods resulting from the growing size of the South within the globalized economy, and capital-skill complementarity combined with the import of capital goods from the North, tend to increase the demand for skill in the South, and thus the skill premium and inequality. In addition, if the South is divided between low income countries (China, India) and middle income countries (Latin America), then the competition from the former can increase inequality in the latter. Moreover, the growing size of the South and productivity catching-up fosters inequality by augmenting the world endowment of efficient unskilled labour. Finally, if openness fosters development, this increases inequality due to Kuznets' mechanism, i.e., a change in the production composition that moves from the traditional to the moderns sector.

There are thus a number of different mechanisms with opposite impacts through which openness and development influence inequality. The empirical literature has sought to assess the intensity of these different determinants. If the studies in cross section of countries are inconclusive as regards the impact of globalization upon inequality, several longitudinal estimates concerning countries taken separately or in small groups of countries reveal a positive correlation between openness and the relative demand for skilled labour. In addition, several works show that openness-driven technological transfers tend to increase inequality in emerging countries. In a way, these diverse results are in line with the theory that describes several mechanisms in the openness-development-growth nexus in developing countries.

We firstly present the stylised facts on the changes in inequality within developing countries during the three last decades (Section 2). We secondly explore the possible theoretical explanations for these observed facts, by distinguishing the 'traditional' (Section 3) from the 'new' (Section 4) explanations. We finally review in Section 5 the empirical literature that assesses the impacts of each of these possible explanations.

\section{Inequality in emerging countries: What the data say}

\subsection{Asian countries}

Asian NICs

According to Krongkaew (1994), a large majority of Asian NICs ${ }^{1}$ experienced a decrease in inequality in the 1980s and Zin (2005) diagnoses a reversal with growing inequality in the 1990s. Solt's (2009) calculations provide a more mixed picture with very different profiles (Figure 1). No clear diagnosis emerges from his countries' trends. 

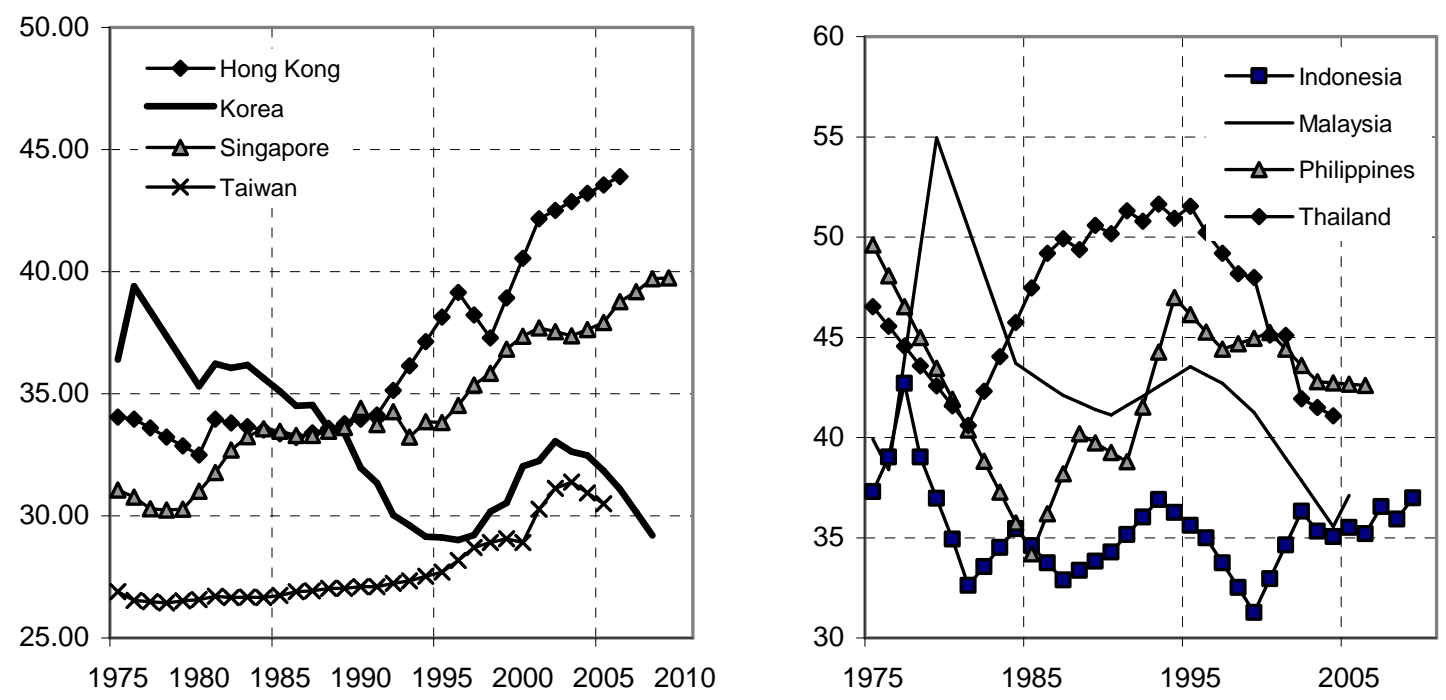

Figure 1: Inequality in Asian NICs (Gini of net income, source: Solt, 2009)

In terms of openness, Asian NICs experienced a significant increase in the seventies, eighties and early nineties. Since then, openness has remained at a high level (Figure 2).

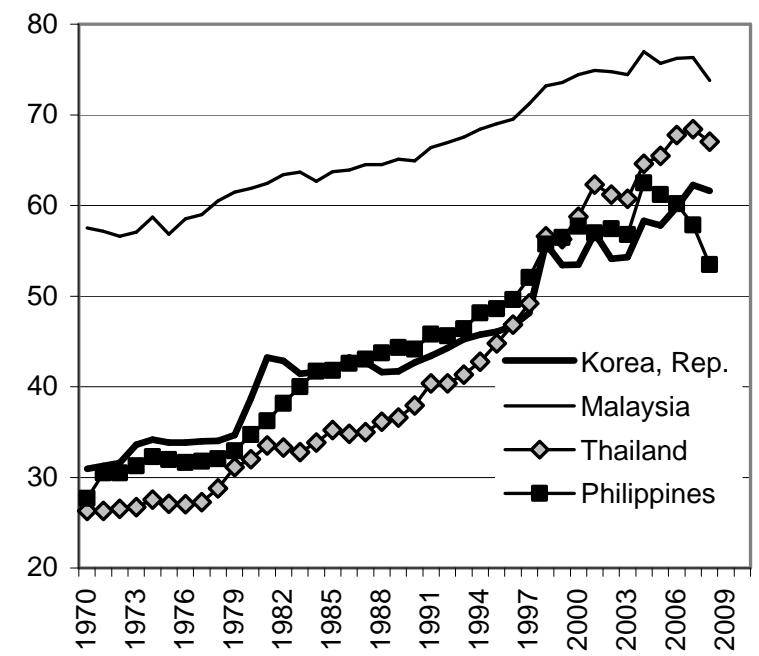

Figure 2: Asian NICs: KOF index of economic globalization

\section{China and India}

The openness of the Chinese economy began in the 1980s and it gathered pace in the 1990s. This trade-driven development has been confirmed since then (Figure 3). In this country, income inequality increased from the early eighties up to the early-2000s (Figure 4). Since then, Cai \& Du (2011) suggest that there has been a reduction in inequality. 


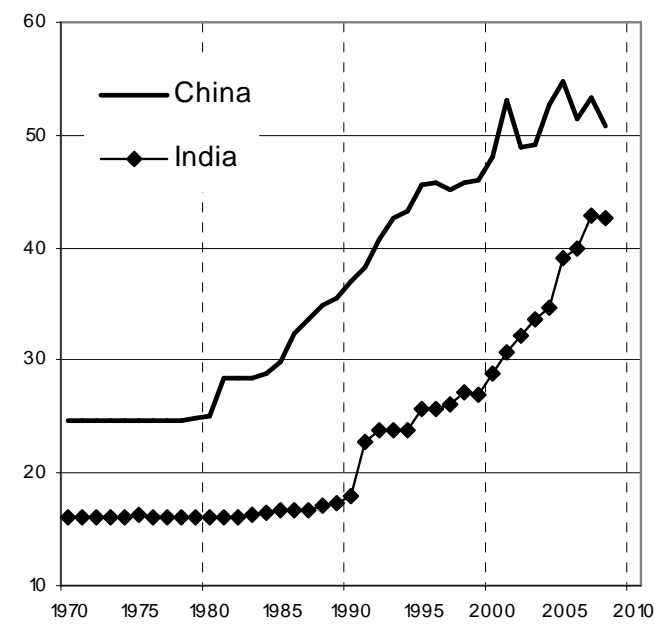

Figure 3: Economic globalization (KOF)

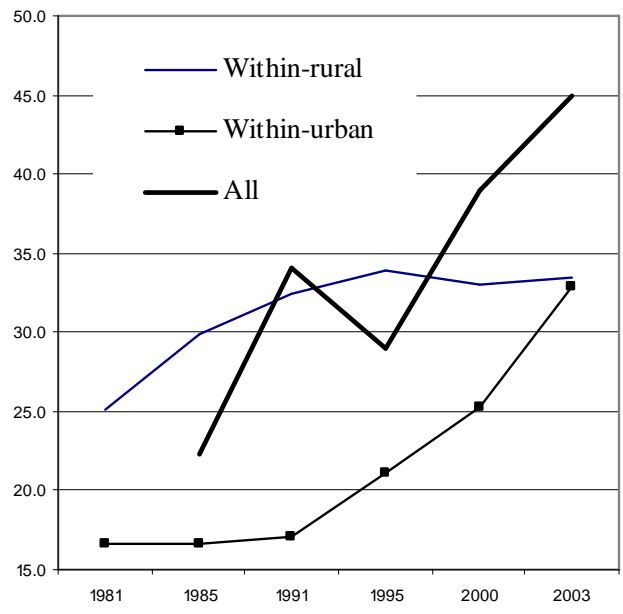

Figure 4: China, Gini, household income (WIID) ${ }^{2}$

The emergence of India as a major player in the globalization process is more recent than for China (Figure 3). The acceleration in openness has coincided with an increase in inequality (Figure 5) as calculated by Solt (2009). This increase is however not very significant given the standard errors of the calculations.

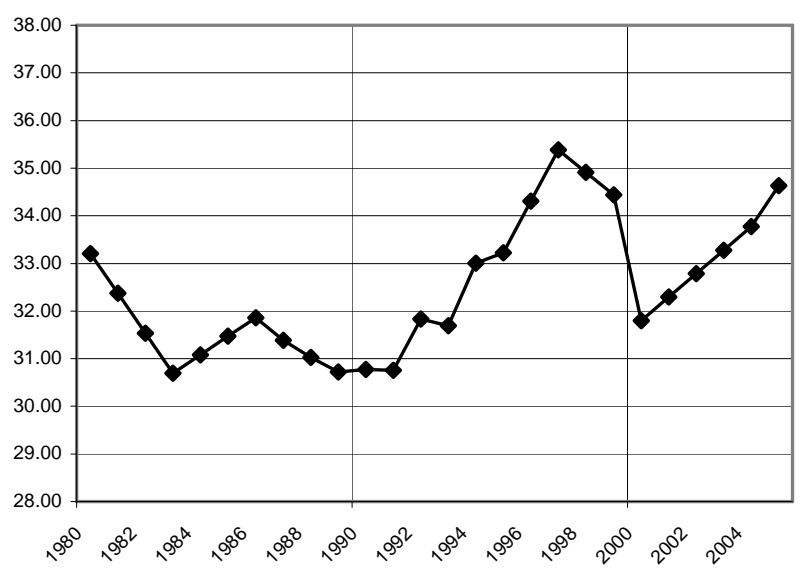

Figure 5: Inequality (Gini of net income) in India (Source: Solt, 2009)

\subsection{Latin America}

\section{Inequality}

Even if there are clear differences between countries, it is possible to diagnose main lines in the profile of inequality in Latin America over the last thirty years (Figure 6). In the eighties, a decrease during the first half of the decade was followed by and increase during the second half (this is clear for the 'four-big' countries, i.e., Brazil, Mexico, Colombia and Argentina). In the 1990s, there was an almost general move towards more inequality, whereas the 2000s 
experienced an almost general decrease in inequality. Of course, (i) the date of the turning points differs across countries and (ii) certain countries (Guatemala, Uruguay) display different profiles.
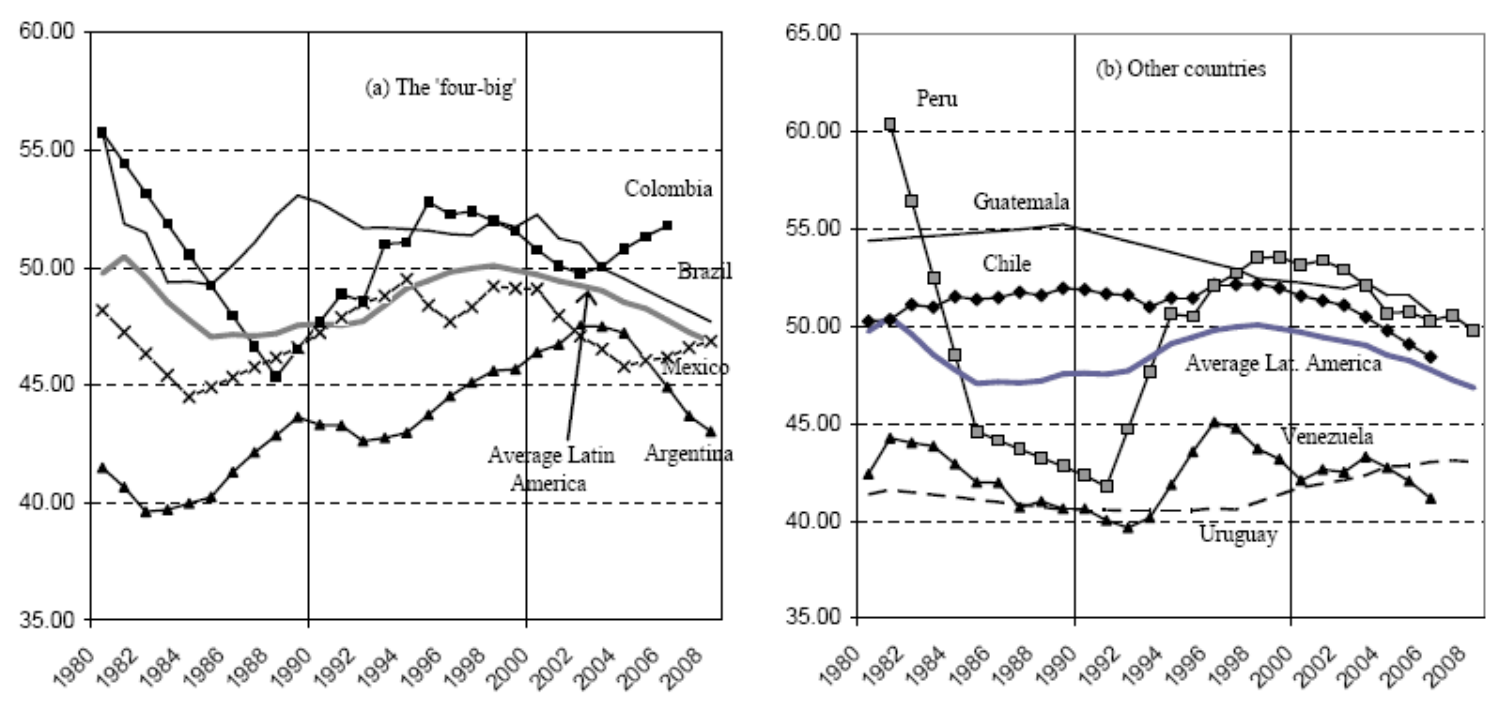

Figure 6: Inequality, Latin America (Gini of net income, 1980-2008. Source: Solt, 2009)

\section{Openness}

Figure 7 depicts the KOF index of globalization for the seven biggest Latin American countries. Globalization has clearly gathered pace since the early nineties.

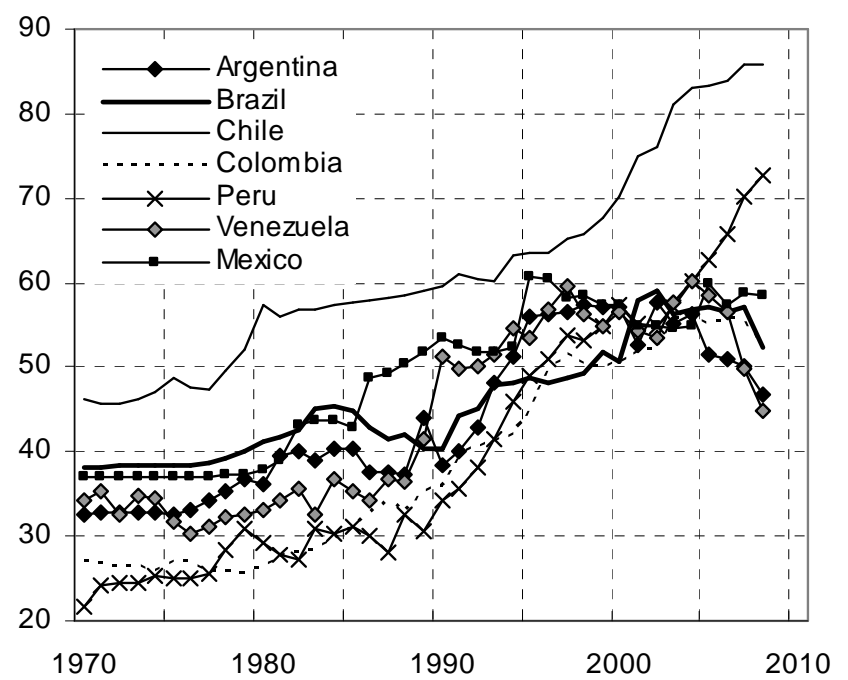

Figure 7: Latin America, KOF index of economic globalization 


\subsection{Other emerging countries}

We do not discuss the changes in inequality for the developing regions such as the middle East and North Africa, or Sub-Saharan African countries. In addition to very different profiles across countries, the main explanations for the long term trends are political and social (wars, revolutions, civil wars, social instability) rather than economical.

Moreover, although the Central and Eastern European countries have experienced an increase in inequality since the fall of the Berlin wall, these economies have been characterised by a transition process and by skill endowments that are rather different from those of other emerging economies. Their precise analysis would deserve a distinctive article. This is the reason why they are not studied here.

\subsection{An inconclusive diagnosis}

On average, the diagnosis can be made of an increase in inequality within emerging countries over the last thirty years. However, this increase appears very uneven across regions and countries, and the shape of inequality throughout the development process is rather contrasted. These miscellaneous changes are pictured on Figure 8.

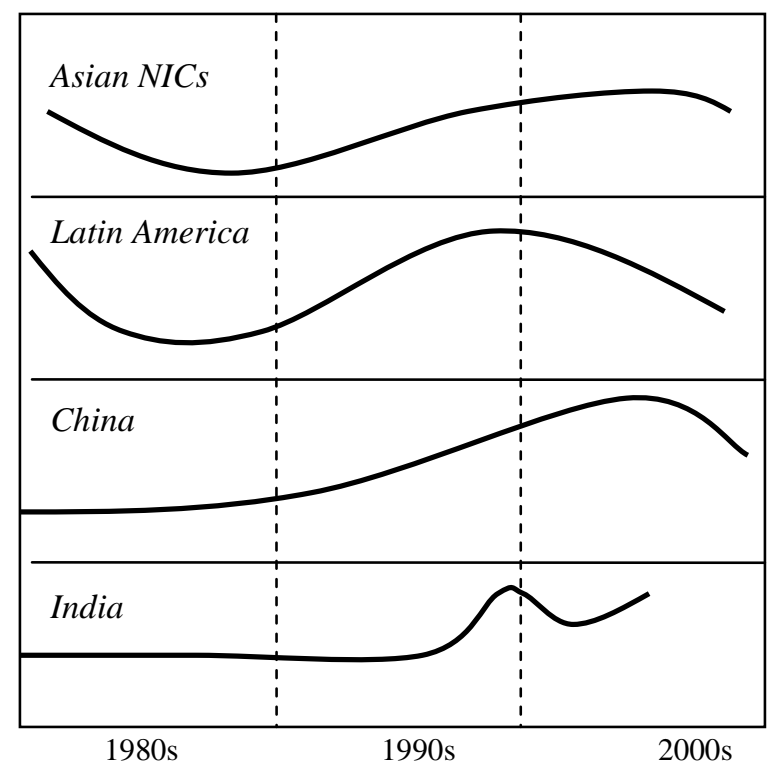

Figure 8: Trends in income inequality over the last thirty years

East Asian countries have successively experienced a phase of growing equality (in the seventies and eighties) and a phase of growing inequality (in the nineties and 2000s).

In contrast, a number of Latin American economies have undergone growing inequalities in the nineties, and a reversal of this shape or a flat evolution from the early 2000s. 
For the last thirty years, inequality has increased in both China and India. In China, increasing inequality can be observed from the early eighties up to the mid-2000s, both between rural and urban areas and within urban and rural areas. From this period, we can note certain indications of a decrease in inequality (Cai \& Du, 2011). In India inequality had decreased from the 1950s up to the mid-1960s, had subsequently remained quasi-constant until the early 2000s, but inequality seems to have increased since then (Solt, 2009; OECD, 2011).

There is thus no clear relationship between the development process and the variation in inequality.

\section{Traditional explanations: Kuznets versus Heckscher-Ohlin}

In emerging countries, the last few decades have been characterised by both a pick up in growth and increasing openness to international trade and FDI. As regards the impacts of development and openness upon inequality, two traditional approaches with opposite predictions can be put forward. The Kuznets approach diagnoses that the first stages of economic development is characterised by an increase in inequality and the following stages by a decrease. In contrast, when development in trade-driven, the North-South HecksherOhlin-Samuelson model (henceforth NS-HOS) diagnoses a decrease in inequality in the South from the moment when openness is implemented.

\subsection{Kuznets' prediction: the inverted- $U$ inequality curve}

As regards the link between development and inequality, Kuznets (1955) seminal article had been commonly accepted by economists until the eighties. Since then, (i) the observations of growing inequalities in the North and unclear variations in the South, and (ii) the mixed results of the econometric works on the subject, have questioned the existence of the Kuznets curve (see the presentation in Hellier \& Lambrecht, 2012).

According to Kuznets (1955), the process of development is characterised by two stages in terms of income inequality. Inequality increases in the first and decreases in the second stage. This draws an inverted-U curve in the plan (level of development ${ }^{3}$, income inequality). Kuznets provides two explanations for this. The first is the mechanical impact of the growing share of the 'modern' sector at the expense of the 'traditional' sector over the development process. A simple presentation of this mechanism is as follows. Suppose that the developing 
economy is characterised by the coexistence of a traditional sector with a low income per worker $I_{T}$ and a modern sector with a higher income per worker $I_{M}>I_{T}$. Development consists of an increase in the share $q$ of the modern sector. Then, inequality measured by the variance of income $q(1-q)\left(I_{M}-I_{T}\right)^{2}$ follows an inverted-U shaped curve over the development process, with the highest inequality being reached for $q=1 / 2$. The second explanation is based on the increase in educational expenditure, redistribution and social security when the country becomes richer, which reinforces the decrease in inequality when income par capita increases.

Kuznets explanation can be complemented by Lewis' analysis (1954). Lewis points to the existence of a turning point in wages during the process of development. This turning point corresponds to the moment when the surplus manpower in the traditional (agricultural) sector comes to an end, thereby stifling the migration flow to the modern sector. From this moment, wages (incomes) begin to rise in both the modern and the traditional sector, typically at the expense of profits, which lowers inequality. Recently, Lewis' turning point has been mobilised so as to explain the pressure on the labour market and the rise of wages in China ${ }^{4}$.

As a result, according to the Kuznets curve, emerging countries should have suffered an increase in inequality at the beginning of their development process. It must however be noted that the related mechanisms do not integrate the impacts of openness (it is typically a closed economy tale), nor the existence of several 'modern' sectors with different factor intensities.

\subsection{The HOS prediction: decreasing inequality}

Let us assume a HOS model with the two factors being high skilled $(H)$ and low skilled $(L)$ labour and the two countries the North and the South. The North is relatively better endowed with $H$ and the South with $L$. This model predicts that openness induces an increase (decrease) in the return to the abundant (scarce) factor in each country, i.e., the unskilled (skilled) labour in the South. This directly stems from the Stolper-Samuelson theorem (see Hellier, 2012, for a comprehensive presentation of the openness-inequality relation in the North-South HOS model). The resulting decrease in the skill premium (ratio of the wage of skilled workers on the wage of the unskilled) means a reduction of inequality.

The NS-HOS model provides an explanation for the South specialisation in trade since southern countries export unskilled-intensive goods and import skill-intensive ones. It can also provide an explanation for the variations in inequality observed in East Asian NICs, provided that the size of the South increases because of the integration of new southern 
countries in the globalized economy (see subsection 4.6. below). However (i) the increase in inequality in a number of emerging countries (Latin America, China, India etc.) seems to contradict the HOS prediction, and (ii) the majority of the NS-HOS predictions are at variance with the observed developments in both the North and the South (Hellier, 2012).

\subsection{The combination of both explanations}

One could argue that the combination of both explanations (Kuznets mechanisms and the NSHOS approach) could generate several different inequality profiles, which is in line with observed facts in developing countries. The rationale of this combination is quite simple: North-South openness reduces inequality in the South through the Stolper-Samuelson mechanism, but it simultaneously increases inequality through the Kuznets mechanism by generating economic development. This ambiguous impact can produce different profiles because the intensity of each mechanism can vary across countries.

However, inserting Kuznets mechanism into the NS-HOS model is not straightforward because this requires modifying certain key assumptions of the HOS approach. In particular, it is necessary to define the traditional sector: (i) does it produce the same homogenous good(s) as the modern economy? What is its technology? How can both a traditional and a modern technology coexist in the same country for the same good(s) with competitive labour markets for both skilled and unskilled labour? Does it involve the two goods or one good only? In the first case, does both traditional productions remain after openness (this is typically impossible with homogenous goods and competitive labour markets)? etc. In addition, a human capital accumulation process must be added to generate growth and development, which requires the introduction of dynamics into the NS-HOS model. All these remarks show that a simple combination of both types of model is just analytically impossible. In fact, certain new hypotheses necessary for this combination are those developed in the new explanations, particularly technological transfers.

\section{New explanations}

Several approaches have been built so as to explain the fact that, in contrast with the StolperSamuelson prediction, North-South openness has come with growing inequality in the South. A first explanation concerns the countries whose development is based on the exploitation of natural resources. When these are in the hands of, or controlled by, a small minority of 
persons, then openness that increases the production and exports of natural resources leads to the enrichment of this minority with a limited impact on the others. This increases inequality. However, this case is not typical of the situations of a large number of emerging countries. We now expose five major explanations that comprise more than five mechanisms because certain explanations encompass several possible channels.

\subsection{The cornering of new skill-intensive goods}

The cornering by the South of new skill intensive goods has been modelled by Feenstra \& Hanson (1996). In their approach, there is a final good that is produced by a combination of intermediate goods that differ in their skill intensity but not in their capital intensity. NorthSouth openness with FDI causes northern firms relocate to the South the less skill intensive intermediate goods. If they are unskilled-intensive for the North, these goods can in contrast be skill-intensive in terms of the South production structure. In this case, international outsourcing (relocation of the production of intermediate goods according to the cost advantage of each country) and FDI (capital transfers from the North to the South) increase the skill premium in the South, i.e., more inequality.

Feenstra \& Hanson (1996) model rests upon both FDI and the international relocation of the production of intermediate goods. There is however a simpler means by which inequality rises through the cornering of new goods. This is when the size of the South increases. We have already noted that assuming a growing size of the South within the NS-HOS model results in an increase in the world skill premium and thus inequality in both the North and the South (Section 2). However, this finding is based on factor price equalisation at the world level, which is clearly at variance with observed facts. To account for this critique, let us assume (i) that the factor endowments are sufficiently different between the North and the South so that there is no factor price equalisation, and (ii) that there is a continuum of final goods that differ in their skill intensity. A simple modelling consists in assuming a continuum of goods $j$ over the interval $[0,1]$ with good $j$ 's production function being $Y_{j}=A\left(H_{j}\right)^{j}\left(L_{j}\right)^{1-j}$ (see Hellier \& Chusseau, 2010). The endowments of each country being given, the model determines a frontier-good $f \in[0,1]$ that is produced by both countries and such that goods $[0, f]$ are produced in the South and goods $[f, 1]$ in the North. Now, an increase in the size of the South entails an increase in the number of goods produced by this area, i.e., an increase in threshold $f$. Consequently, the South produces new more skill 
intensive goods, which raises the relative demand for skilled labour and thus the skill premium. Finally, inequality increases in the South.

\subsection{Technological transfers}

The NS-HOS framework assumes identical and unchanged technologies in the North and the South before and after openness. A more realistic position consists in assuming technological transfers from advanced to emerging countries. This is all the more likely as (i) northern technologies are typically more performing than southern ones, and (ii) northern multinational firms can invest in the South and produce with their own technologies. For technological transfers to increase the demand for skill and the skill premium, the new technologies adopted by the South must be more skill intensive. However, even without differences in skill intensity between the initial and the transferred technologies, the adoption of new technologies entails a transitory increase in inequality when it requires a transitory use of skilled workers.

\section{Transitory increase in inequality}

The idea that introducing and implementing new technologies requires a transitional period during which skilled workers are employed to adapt the firms' organisation and manpower to this technology had been developed to explain both Solow's paradox and increasing inequality in northern countries in the 80s and early 90s (Greenwood \& Yorukoglu, 1997; Helpman \& Trajtenberg, 1998; Caselli, 1999; Jacobs \& Nahuis, 2002). Applied to the case of technological transfers from advanced to developing countries, this creates a temporary rise of the skill premium.

\section{Lasting increase in inequality}

Suppose that the northern technologies are more skill intensive that the southern ones, which is a rather realistic assumption. Since the South is internationally specialised in low skill intensive goods, the adoption of the northern technology incurs an extra cost because skilled labour is already the scarce and expensive factor in the South. For the South to adopt the northern technology, the related increase in total factor productivity must offset this additional cost. If so, the northern technology is implemented in the South, which entails both increasing income per capita (from the rise of TFP) and increasing inequality (because the higher demand for skilled workers raises the skill premium). 
A synthesis

Pissarides (1997) has developed a model in which openness can result in both transitory and lasting inequality in the South. In his approach, the introduction in the South of new more productive technologies from the North requires a transitory utilisation of skilled workers, which involves a temporary increase in the skill premium. This increase can be lasting when the new technology is sufficiently skill intensive. Consequently, Pissarides' approach results in an increase in inequality at the first stage of the technology transfer, this increase being transitory or lasting depending on the skill intensity of the new technology.

\subsection{Changes in the sectoral structure with non tradable goods}

Wood (2002) analyses the impact of lower travel and communication costs (one characteristic of globalization) within a model where the South is endowed with unskilled and medium skilled workers. The South produces non tradable and tradable goods from unskilled and medium skilled labour, but the tradable goods additionally require the utilisation of high skilled workers imported from the North. The decrease in travelling and communication costs shrinks the cost of importing skilled workers from the North, which increases the production of tradables at the expense of non tradable goods. This can cause both higher or lower inequality in the South, depending on whether the new tradables produced in this area are more or less medium skill intensive than the non-tradables. As a matter of fact, when openness results in an increase in the production of tradables at the expense of non-tradables, this generates higher inequality if the former is more skill intensive than the latter.

\subsection{FDI and capital imports from the North}

The critical increase in FDI, capital transfers and exports of capital goods from the North to the South is one of the main characteristics of globalization. These moves have been made possible by the huge rise in capital mobility during the last thirty years. There are several means by which FDI and imports of capital goods from the North can foster inequality in the South: capital-skill complementarity, embedded technologies, higher pay by northern multinational firms (MNFs) etc.

\section{Capital-skill complementarity}

Suppose (i) that production necessitates the utilisation of capital $K$, skilled labour $H$ and less skilled labour $L$, and (ii) that the production functions (technologies) are such that skilled 
labour and capital are complementary factors. There is absolute capital-skill complementarity when an increase in the use of $K$ entails an increase in the use of $H$ whereas $K$ and $L$ are substitutable. There is relative complementarity when $K$ is more substitutable for $L$ than for $H$. In both cases, an increase in capital utilisation raises the relative demand for skill $H / L$.

Let us assume now that trade liberalisation leads to the South importing northern capital goods because these are more productive, and thus to an increase in the use of capital in the South. Because of capital-skill complementarity, this raises the relative demand for skill $H / L$ and thus the skill premium and inequality. Such a mechanism can be found in Acemoglu (2003).

\section{FDI and multinational firms (MNFs)}

We have already noted the crucial role of FDI in Feenstra \& Hanson (1996)'s approach (see 4.1.). In addition, FDI can be the vector through which technological transfers take place, resulting in higher demand for skilled labour and higher skill premium. However, FDI can directly cause inequality if northern MNFs pay more their manpower than domestic firms.

The fact that MNFs from advanced countries provide better pay is now well documented. Lipsey (2002) notes that this is confirmed by almost all empirical works. In addition, studying the Indonesian case, Lipsey \& Sjoholm (2001) report that the MNFs' wage premium was about $25 \%$ for unskilled workers and $50 \%$ for the skilled. This premium depicts the fact that northern MNFs provide their workers with know-how, advanced skills and organisational abilities. MNFs consequently allow an over-pay to prevent manpower turnover. In addition, since the skills provided by learning-by-doing and training is higher in the case of skilled than in that of unskilled workers, the premium is higher for the former than for the latter. The MNFs' wage premium has two impacts in terms of income inequality. It firstly generates an FDI-driven Kuznets effect since workers are better paid in the 'modern' (MNFs) than in the 'traditional' (domestic) sector. It secondly increases the skill premium in the 'modern' sector since the MNFs premium is higher for skilled than for unskilled workers.

\subsection{Intermediate emerging countries}

Within a simple North-South two-country model, specialisation in trade typically fosters the production of unskilled-intensive goods in the South. However, by introducing new countries with unskilled labour costs in-between those of the North and the South, there is room for growing inequality in these intermediate countries. 
A rather simple HOS framework with the North $(\mathrm{N})$ and two southern countries (S1 and S2) showing different unskilled labour endowments can easily produce such a result. By assuming that $\mathrm{S} 2$ is relatively more skill endowed than $\mathrm{S} 1$, the before-openness (autarkic) skill premia hierarchy is $\omega_{N}<\omega_{S 2}<\omega_{S 1}$, with $\omega_{i}$ being country $i$ ' s skill premium. Openness results in factor price equalisation with the world skill premium $\omega_{W}$ being in between $\omega_{N}$ and $\omega_{S 1}$. Then, $\omega_{W}$ can be either higher or smaller than $\omega_{S 2}$ depending on the size of each Southern country and on the endowments differences between N, S2 and S1. In particular, when S1 (China + India) is significantly bigger than S2 (Latin America), then openness raises the skill premium and inequality in the latter.

\subsection{Growing South and technological catching up}

Within the HOS model, North-South openness lessens inequality in the South through the Stolper-Samuelson effect. However, within the same model, there are two channels through which openness can in contrast increase inequality in emerging countries. The first consists in increasing the size of the South. The goal is here to display the fact that new emerging regions and countries continuously join the globalized economy. Since these new comers are highly endowed with unskilled labour, this leads to a rise in the relative endowment of unskilled labour of the globalized economy, and thereby to an increase in the skill premium and inequality in those southern countries that were already globalized (Hellier, 2012). Another extension consists in assuming that total factor productivity is higher in the North than in the South at the outset of globalization, and that the South subsequently catches up the northern productivity. It can be shown that this is equivalent to an increase in the size of the South, with the same impact on the skill premium, i.e., rising inequality.

\subsection{Assessment}

Table 1 summarises the main channels through which development, globalization and technical progress impact on inequality in developing countries. It is clear that a number of mechanisms with opposite impacts are at work.

The Stolper-Samuelson effect lessens inequality. Kuznets hypothesis as well as Lewis turning point predict a rise of inequality during the first stage of development and a decrease afterwards. The cornering of more skill intensive goods, technological transfers, foreign direct investments from northern countries, the growing size of the South and catching up in 
productivity are inequality-enhancing. Finally, changes in the structure of production (tradables/non-tradables) and the hierarchy of skill endowment at the world level may lead either to higher or to lower inequality, depending on the sectoral skill intensities and on the country's position on the skill endowment ladder. It can be noted that the different dimensions of the globalization process are at the core of a majority of explanations. These dimensions are the pattern of trade within a North-South specialisation framework, FDI, technological transfers from the North, the entry of new emerging countries into the globalized economy. Finally, the government policies in terms of labour market institutions and education also influence the moves in inequality in the short as well as in the longer term.

Table 1 The mechanisms influencing inequality in emerging countries

\begin{tabular}{|c|c|}
\hline Channels & Impact on inequality in emerging countries \\
\hline Kuznets hypothesis and Lewis turning point & $\begin{array}{l}\text { Positive: Inequality increases during the first stage of } \\
\text { development, and decreases afterwards. }\end{array}$ \\
\hline Stolper-Samuelson effect & $\begin{array}{l}\text { Negative: Decrease in inequality in emerging } \\
\text { countries when North-South openness occurs }\end{array}$ \\
\hline Cornering of new more skill intensive goods & $\begin{array}{l}\text { Positive: Increase in the skill premium, i.e., in } \\
\text { inequality. }\end{array}$ \\
\hline Technological transfer & $\begin{array}{l}\text { Positive: Transitory increase in inequality due to the } \\
\text { demand for skilled workers to adapt to the new } \\
\text { technology, and lasting increase when the new } \\
\text { technology is sufficiently skill intensive. }\end{array}$ \\
\hline $\begin{array}{l}\text { Increase in the production of tradables at the } \\
\text { expense of non-tradables. }\end{array}$ & $\begin{array}{l}\text { Indeterminate: Different possible outcomes } \\
\text { depending on factor intensity in each sector. }\end{array}$ \\
\hline Foreign Direct Investment from the North & $\begin{array}{l}\text { Positive: Increase in inequality deriving from capital } \\
\text { skill complementarity and lor the wage policy of } \\
\text { MNFs. }\end{array}$ \\
\hline $\begin{array}{l}\text { Growing size of the South and productivity } \\
\text { catching up }\end{array}$ & $\begin{array}{l}\text { Positive: Increase in inequality (the skill premium) } \\
\text { due to higher (efficient) unskilled labour endowment } \\
\text { at the world level. }\end{array}$ \\
\hline Intermediate country & $\begin{array}{l}\text { Indeterminate: depending on the position of the } \\
\text { country on the skill endowment ladder. }\end{array}$ \\
\hline
\end{tabular}

This large set of possible channels and their contradictory impacts lead to the conclusion that a number of very different profiles may coexist, depending on the weight of each mechanism and on the countries' specificities. This conclusion is in accordance with the observed differences between countries and regions put forward in Section 3. This shows the need to assess the impacts of each determinant and of the countries' characteristics upon the changes in income distribution. 


\section{Empirical evidence}

\subsection{Methods}

Openness and income inequality

A first set of approaches aim at measuring the effects of increasing openness upon income or wage inequalities in a cross section of countries. These analyses regress the level of inequality on the level of openness. They usually use aggregate measures of overall inequality such as the Gini coefficient or the share in national income of the bottom 20\%. The main globalization variables are FDI inflows, trade (both as percent of GDP), or existing synthetic indicators as the KOF globalisation index. Other variables depicting the integration in the world economy are also used (e.g., intellectual property rights enforcement). A set of control variables that affect inequality are typically introduced into the regression (education, working sector, gender, age, capital per worker, real exchange rate, level of development, government size, etc.). Technology indicators (such as imports of capital goods or imports of goods incorporating technological upgrading from advanced countries) can also be inserted.

Three mains empirical relations are tested corresponding to three different hypotheses concerning the impact of openness upon inequality (Anderson, 2005). First, greater openness increases overall inequality in all countries. A second hypothesis that emanates from the HOS approach is that greater openness reduces inequality in developing countries, but increases inequality in developed countries. Finally, the third hypothesis consists in estimating the HOS mechanisms by introducing the impact of factor endowment. The higher one factor's relative endowment, the greater the effect of an increase in openness on its relative return.

\section{Openness and the skill premium}

A second set of studies has estimates the effect of openness on the skill premium. The goal is to determine the share of the changes in relative wages that can be attributed directly or indirectly to openness (Sections 3 and 4). Three main channels can be tested. First, according to the HOS approach, a reduction in the barriers to trade disminishes the skill premium in emerging countries (Section 3). Second, a reduction in the barriers to FDI can shift the structure of production towards more skill intensive sectors, which increases the skill premium (see subsections 4.3, 4.4 and 4.6). Third, a reduction in the barriers to both trade and FDI increases the utilisation of foreign skill-intensive technologies by firms, which increases 
the skill premium (subsections 4.2, and 4.4). This third channel goes through the impact of openness upon the technology utilised by the South.

Two main empirical methods are used to test these hypotheses: the supply and demand approach and the cost function approach (Anderson, 2005).

The supply and demand approach consists in estimating the impact of trade or technology indicators, on the relative wage of skilled workers, controlling for relative supply. If the effect is significant, it can be concluded that openness or foreign technology affect the relative demand for skill.

The cost function approach consists of direct estimations of the impact of several foreign technology indicators on the share of skilled wages in total wage bill, using flexible cost functions (usually a translog cost production function) and controlling for the relative wage. The share of skilled wages in the total wage bill depends on the skill premium, on the capital used in production, on the value added and on the type of technology used by the firm. Finally, other studies use mandated wage regressions (Leamer, 1998) to test the StolperSamuelson theorem and isolate the impact of technology from trade on factor prices (skill premium). The change in relative wages due to a shift in productivity reveals the impact of technological change. Any change in relative wages due to other factor than productivity is interpreted as the effect of globalization.

\section{Openness and employment}

The factor content of trade is used to evaluate the number of jobs created or destroyed by openness. This method consists in calculating the amounts of skilled and unskilled labour (i) that are contained in the production of goods exported by a country and (ii) that would be necessary to produce the imported goods if these were domestically produced. The difference measures the net impact of trade on the demand for skilled and unskilled labour. CGE models are built and simulated to estimate the effects of changing trade patterns on employment and incomes.

\subsection{Assessing the Kuznets hypothesis}

A large amount of empirical studies have sought to assess Kuznets hypothesis (KH). This literature is described in Hellier and Lambrecht (2012). The results are not really conclusive. On the one hand, most of the estimates in cross section of countries seem to confirm $\mathrm{KH}$. On the other hand, the results are rather diverse in relation to the turning point and they are often not conclusive when longitudinal analyses are considered and countries taken separately. 


\subsection{Overall estimations}

A weak impact of greater openness on income inequality

Anderson (2005) reviews several recent empirical works that study the effects of greater openness on inequality in developing countries. Most cross-country studies reveal that openness has had a weak impact on overall income inequality after controlling for other observable determinants of inequality (White \& Anderson, 2001; Edwards, 1997; Calderon \& Chong, 2001; Ravallion, 2001; Barro; 2000; Lundberg \& Squire, 2003). In addition, several longitudinal studies of countries taken separately or of small groups of countries show that openness has strengthened the relative demand for skilled labour (Robbins, 1996; Beyer et al., 1999; Gindling \& Robbins, 2001; Robbins \& Gindling, 1999; Green et al., 2001; Feenstra \& Hanson, 1997; Te Velde \& Morrissey, 2004; Te Velde, 2003). These two results contradict each other. One possible explanation is that openness influences income inequality through other channels than that featuring the relative demand for skilled labour. As an example, Anderson (2005) suggests that increase in the relative demand for skill could have been offset by a decrease (i) in the average gender wage gap, (ii) in average incomes in core relative to peripheral regions, and (iii) in the level of human capital inequality.

\section{Technological transfers and skill-biased technological change}

From a sample of low and middle income countries, Conte \& Vivarelli (2007) study the impact of technological transfer on the employment of skilled and unskilled labour. Technological transfer is measured as the imports from industrialised countries of those goods that incorporate technological upgrading. They find that imported skill-biased technological change is an influential determinant of the increase in the relative demand for skilled workers within developing countries in the 1980s. This suggests that openness-driven technological change may explain the increased demand for skilled labour in the South.

From a sample of 65 developing countries over the period 1980-1999, Meschi \& Vivarelli (2008) use a dynamic specification to estimate the impact of trade upon within-country income inequality. The dependent variable is the estimated household income inequality (EHII) provided by the University of Texas Inequality Project (UTIP). The independent variables are (i) international trade variables (alternatively total trade, imports and exports according to their origin/destination areas) and (ii) a set of control variables that depict the level of development, the skill supply and the macroeconomic environment. The results suggest that trade with high income countries worsens income distribution in developing 
countries both through imports and exports, whereas trade with other developing countries have the opposite effect. The authors interpret these findings as upholding the hypothesis that technological differences between trading partners play a relevant part in explaining the distributive impact of globalization. In addition, these previous results only hold for middle income countries suggesting that these have the greater potential for technological upgrading.

\section{A stronger influence of intellectual property rights}

Adams (2008) examines the impact of globalization on income inequality for a cross-section of 62 developing countries over a period of 17 years (1985-2001). He lays a special emphasis on the impact of intellectual property rights (IPRs). The dependent variable is the Gini coefficient. The independent variables comprises globalization variables (FDI inflows share in GDP, integration in to the world economy measured as trade share in GDP, IPRs), and other variables such as the country's population, human capital (the gross secondary school enrolment), the level of development (GDP per capita), the Government consumption, and a proxy for institutional or governance infrastructure ${ }^{5}$. The results indicate that globalization has a positive and significant impact on income inequality, but explains only $15 \%$ of the variance in income inequality. The strengthening of IPRs produces a significantly positive effect on income inequality. Foreign direct investment may reduce income inequality in developing countries (negative and significant coefficient) but this result is not robust for several model specifications. In addition, the institutional infrastructure is negatively correlated with income inequality suggesting that institutions may offset the negative impact of globalization.

\subsection{Asian countries}

Asian NICs

East Asian countries experienced a decrease in income inequality after the trade liberalisation and the development of exports introduced in the 1960s and 1970s.

Wood (1994, 1999) finds rising demand for unskilled labour and decline in wage inequality in South Korea, Taiwan and Singapore following trade liberalisation. Openness has reduced income inequality and stimulated employment. After China's FDI liberalization in the late 1970s, Hong Kong reallocated much of its unskilled labour intensive production facilities to China, and thus outsourced a large share of its production. Hong Kong specialized in turn in skill intensive manufacturing activities and outsourcing based services such as 
marketing or distribution. Hsieh \& Woo (2005) find a large increase in the relative demand for skilled in Hong Kong after China's reforms. For Korea, Kang (2001) shows that international trade (especially exports) concentrating more on skilled labour-intensive products, tended to heighten wage inequality.

\section{China}

Benjamin et al. (2005) measure the effect of trade liberalisation on income inequalities in China from 1987 up to 2001. They find that income inequalities increased in urban districts. This rise in inequality seems to coincide with the openness of the Chinese economy, suggesting that China's economic transition could have affected income inequalities in urban areas. Income inequality has also risen in rural districts, but this increase has been lower than that observed in urban districts.

Over the twenty last years, China has received enormous amounts of foreign direct investments. Chen at al. (2011) examine the link between FDI and inequality. They find that FDI increases inter-enterprise wage inequality. A first reason is that foreign firms offer higher wages, whereas private domestic and collectively-owned firms have lower wage levels. In addition, wage growth in multinationals is significantly higher than that in domestic firms.

Finally, the recent increase in wages observed in Chinese urban districts has been interpreted by certain economists as resulting from the Lewis turning point. This hypothesis has been tested. Its relevance is defended by Cai \& Du (2011) and Zhang et al. (2011). It is in contrast challenged by Ge \& Tao Yang (2011) who find no support for Lewis turning point.

\section{India}

Empirical studies reveal a rather mixed effect of openness on income and wage inequality in India.

Using district-level data from 1983 to 2000, Topalova (2005) finds that the development of trade had no effect upon income inequality (in both urban and rural districts), whereas it increased poverty in rural areas. Chamarbagwala (2006) argues that rising wage inequality between skilled and unskilled workers is due to an increase in the relative demand for skill within industries (particularly within services) rather than to trade liberalisation. Dutta (2007) shows that workers in industries with higher tariffs had higher wages before liberalization. These industries employed a large amount of unskilled workers, and were the most affected by tariff cuts, which reduce the protection from which unskilled workers benefited. The author concludes that trade liberalisation may have increased wage inequality between skilled 
and unskilled workers. In contrast with the preceding results, Kumar \& Mishra (2008) find that increasing openness has reduced wage inequality between skilled and unskilled workers. Within a CGE model, Kucera. \& Roncolato (2011) use social accounting matrices and Leontief multipliers to estimate the effects of trade liberalisation from 1993 to 2004 on employment and incomes. They make a distinction between trade with developed and developing countries. They find that trade liberalisation shed 2.3 million jobs (with 75 per cent of the loss resulting from trade with developing countries) and entailed higher income inequality. The negative effect that results from trade with developing countries is higher for labour incomes than for the capital incomes.

\subsection{Latin America}

For Latin America, the empirical literature suggests a relationship between trade liberalisation, wage inequality and employment that is at odds with the predictions of the HOS theory.

Márquez \& Pagés (1997) find for 18 Latin American countries that trade reforms had had a negative effect on the employment growth rate.

Green et al. (2001) show that trade liberalisation in Brazil provoked a substantial rise in the returns to college education because of increasing relative demand for skilled workers. However, they find no change in overall wage inequality. For the same country, Maia (2001) examines the impact of trade and technology on skilled and unskilled labour before and after trade liberalisation. She concludes that trade destroyed more unskilled than skilled jobs and that technology created a large amount of skilled and destroyed millions of unskilled jobs.

Feenstra \& Hanson (1997) show that the American 'maquiladoras' in the north of Mexico have sparked a significant increase in the relative demand for skilled workers in the border region with the US, where there is a large concentration of foreign direct investment. Hanson \& Harrison (1999) examine the changes in wages and employment of skilled and unskilled workers after trade liberalisation in Mexico. They find little variation in employment levels, but a significant increase in skilled workers' relative wages. However, in contrast with the Stolper-Samuelson prediction, they find no correlation between the intensity of skilled labour and changes in relative prices.

Galiani \& Sanguinetti (2003) estimate the correlation between trade liberalisation in Argentina during the nineties and growing wage inequalities over the same period. They examine whether those sectors where trade liberalisation produced larger effects are those 
with a higher rise in wage inequality. They find a positive and significant correlation between the rise in import penetration ratios and the rise in the college wage premium observed in Argentina during the nineties. However, trade liberalisation can only explain a relatively small proportion of the observed increase in wage inequality.

Robbins \& Gindling (1999) find that the skill premium increased after liberalisation in Costa Rica as a result of the changes in the structure of labour demand.

\subsection{Other countries}

Several works analyse the effects of trade liberalisation implemented since the early 1990s in South Africa. These approaches estimate the effect on income inequality and on employment. As for other developing countries, they find rather mixed evidence. Edwards (2004b) finds that tariff reductions had a negative effect on wages compared to returns to capital between 1988 and 2002, and then increased income inequality between labour and capital. Thurlow (2006) and Cockburn et al. (2007) use a Computable General Equilibrium (CGE) model based on factor content of trade to simulate the effects of tariff reductions on income inequality. They find that tariff reductions increased income inequality. However, in contrast to Thurlow, they find that tariff reductions widened the gender wage gap and deepened poverty. Edwards (2004a) shows that import penetration between 1997 and 2000 had a negative effect on employment in large firms, but not in small firms. Moreover, employment in export-oriented firms declined a lot, particularly for the unskilled suggesting that trade expansion increase the relative demand for skilled workers. Kucera \& Roncolato (2011) estimate the impact of trade liberalisation from 1993 to 2004. They show that South Africa has gained employment from trade with developed countries and lost employment from trade with developing countries. Trade liberalisation increased income inequality.

\section{Conclusion}

Over the last thirty years, the variation of inequality within developing countries has been rather diverse. Even if the general diagnosis is that of an increase in inequality, the profiles are different across countries and across groups of countries (Asian NICs, Latin America, China, India etc.) and the most recent variations seem to point to a return to more egalitarian growth paths. The theoretical explanations are also diverse. Several mechanisms are at work with opposite impacts. If globalisation is at the core of a majority of explanations, the 
insertion into the world economy creates different and contradictory mechanisms. The Stolper-Samuelson effect lowers inequality, as well as growth-related pro-education policies. On the other hand, technological transfers, the cornering of new skill intensive industries, the increase in the size of the South and technological catching up tend to increase inequality. Finally, the empirical literature is rather contradictory. On the one hand, most cross-country studies find a weak impact of globalization on income inequality. On the other hand, several longitudinal studies concerning countries taken separately or small groups of countries reveal a positive correlation between openness and the relative demand for skilled labour, thereby increasing inequality. These apparently conflicting findings are not surprising given the different and opposite mechanisms linked to globalisation. One can logically expect different profiles depending on the weight of each mechanism in the different countries and over time.

\section{References}

Acemoglu, D. (2003) 'Patterns of skill premia', Review of Economic Studies, 70(2), 199-230.

Adams, S. (2008) 'Globalization and income inequality: Implications for intellectual property rights', Journal of Policy Modelling, 30, 725-35.

Anderson, E. (2005) 'Openness and Inequality in Developing Countries: A Review of Theory and Recent Evidence', World Development, 33(7), 1045-63.

Arbache, J.S. (2001) 'Trade liberalisation and labour markets in developing countries: Theory and evidence', Mimeo, University of Brasilia and University of Kent.

Barro, R. (2000) 'Inequality and growth in a panel of countries', Journal of Economic Growth, 5(1), 532.

Benjamin, D., L Brandt, J. Giles and S. Wang (2005), 'Income Inequality During China's Economic Transition', prepared for Brandt L. and T.G. Rawski (eds), China's Great Economic Transformation, forthcoming volume, Cambridge University Press.

Beyer, H., P. Rojas and R. Vergara (1999) ,Trade liberalization and wage inequality', Journal of Development Economics, 59(1), 103-23.

Cai, F. and Y. Du (2011) 'Wage increases, wage convergence, and the Lewis turning point in China', China Economic Review, 22, 601-10

Calderon, C. and A. Chong (2001) 'External sector and income inequality in interdependent economies using a dynamic panel data approach', Economics Letters, 71(2), 225-31.

Caselli, F. (1999) 'Technological Revolutions', American Economic Review, 89 (1), 78-102.

Chamarbagwala, R. (2006) 'Economic liberalization and wage inequality in India', World Development, 34(12), 1997-2015.

Chen, Z., Y. Ge and H. Lai (2011) 'Foreign Direct Investment and Wage Inequality: Evidence from China', World Development, 39(8), 1322-32.

Chusseau, N., M. Dumont and J. Hellier (2008) 'Explaining Rising Inequality: Skill-biased technical Change and North-South Trade', Journal of Economic Surveys, 22(3), 409-57.

Cockburn, J., I. Fofana, B. Decaluwe, R. Mabugu and M. Chitiga (2007) 'A gender-focused macromicro analysis of the poverty impacts of trade liberalization in South Africa' in: P.J. Lambert (ed.) Research on Economic Inequality, Vol. 15: Equity (Amsterdam, Elsevier/JAI Press), 269-305.

Conte, A. and M. Vivarelli (2007) 'Globalization and employment: Imported skill biased technological change in developing countries', IZA Discussion Paper No. 2797, IZA, Bonn.

Cooper, R. (2002) Growth and inequality: The role of foreign trade and investment, Annual World Bank Conference on Development Economics, 2001/2002 (World Bank). 
Crafts, N. (2004) 'Globalization and Economic Growth: A Historical Perspective', World Economy, 27(1), 45-58.

Dutta, P.V. (2007) 'Trade protection and industry wages in India', Industrial and Labor Relations Review, 60(2), 268-86.

Edwards, S. (1997) 'Trade policy, growth and income distribution', American Economic Review, 87(2), 205-10.

Edwards, L. (2004a) 'A firm level analysis of trade, technology and employment in South Africa', Journal of International Development, 16(1), 45-61.

Edwards, L. (2004b) 'Trade liberalisation and factor returns in South Africa, 1988-2002', Paper prepared for the Conference on "African development and poverty reduction: The macro-micro linkage', Cape Town, 13-15 October

Feenstra, R and G. Hanson (1996) 'Foreign Investment, Outsourcing and Relative Wages', NBER Working Paper No.5121.

Feenstra, R and G. Hanson (1997) 'Foreign direct investment and relative wages: Evidence from Mexico's maquiladoras', Journal of International Economics, 42(3-4), 371-93.

Galiani, S. and P. Sanguinetti (2003) 'The impact of trade liberalization on wage inequality: evidence from Argentina', Journal of Development Economics 72, 497-513.

Gasparini, L. and N. Lustig (2011) 'The rise and fall of income inequality in Latin America', ECINEQ Working Paper Series, No. 2011-213.

Ge, S. and D. Tao Yang (2011) 'Labor market developments in China: A neoclassical view', China Economic Review, 22(4), 611-25.

Gindling, T. H. and D. Robbins (2001) 'Patterns and sources of changing wage inequality in Chile and Costa Rica during structural adjustment', World Development, 29(4), 725-45.

Goldberg, P.K. and N. Pavcnik (2007) 'Distributional Effects of Globalization in Developing Countries', Journal of Economic Literature, 45, 39-82.

Green, F., A. Dickerson and J.S. Arbache (2001) 'A picture of wage inequality and the allocation of labour through a period of trade liberalization: The case of Brazil', World Development, 29(11), 1923-39.

Greenwood, J. and M. Yorukoglu (1997) '1974', Carnegie-Rochester Conference Series on Public Policy, 46(2), 49-95.

Hanson, G.H. and A. Harrison (1999) 'Trade Liberalization and Wage Inequality in Mexico', Industrial and Labor Relations Review, 52, 271-88.

Hellier, J. (2012, Forthcoming) 'The North-South HOS model, Inequality and Globalization', in: J. Hellier \& N. Chusseau Eds., Growing Income Inequalities, Chapter 4, Palgrave MacMillan. An early version of the paper can be found in ECINEQ WP No. 2012-244.

Hellier, J. and N. Chusseau (2010), 'Globalization and the Inequality-Unemployment Tradeoff', Review of International Economics, 18(5), 1028-43.

Hellier, J. and S. Lambrecht (2012, Forthcoming) 'Inequality, Growth and Welfare: The Main Links', in: J. Hellier \& N. Chusseau Eds., Growing Income Inequalities, Chapter 9, Palgrave MacMillan.

Helpman, E. and M. Trajtenberg (1998) 'A time to sow and a time to reap: Growth based on General Purpose Technologies', in E. Helpman (ed.), General Purpose Technologies and Economic Growth, (Cambridge, MIT Press).

Hsieh, C-T. and K.T. Woo (2005) 'The Impact of Outsourcing to China on Hong Kong's Labor Market', American Economic Review, 95(5), 1673-87.

Jacobs, B. and R. Nahuis (2002) 'A general purpose technology explains the Solow paradox and wage inequality', Economics Letters, 74, 243-50.

Kang, S. (2001) 'Globalization and income inequality in Korea: an overview', paper for the FDI, Human Capital and Education In Developing Countries Technical Meeting, OECD Development Centre, Paris, 13-14 December.

Krongkaew, M. (1994) 'Income Distribution in East Asian Developing Countries: an update', AsianPacific Economic Literature, 8(2), 58-73.

Kucera, D. and L. Roncolato (2011) 'Trade liberalization, employment and inequality in India and South Africa', International Labour Review, 150(1-2).

Kumar, U. and P. Mishra (2008) 'Trade liberalization and wage inequality: Evidence from India', Review of Development Economics, 12(2), 291-311. 
Kuznets, S. (1955) 'Economic Growth and Income Inequality', American Economic Review, 45, 1-28.

Leamer, E.E. (1998) 'In search of Stolper-Samuelson linkage between international trade and lower wages' in S. Collins (ed.) Imports, Exports and the American Worker (Brooking Institutions), 141202.

Lewis, W.A. (1954), 'Economic Development with Unlimited Supply of Labour', The Manchester School, 22, 139-91.

Lipsey, R. E. (2002) 'Home and Host Country Effects of FDI', NBER Working Paper, No. 9293.

Lipsey, R.E. and F. Sjoholm (2001) 'Foreign Direct Investment and Wages in Indonesian Manufacturing', NBER Working Paper, No. 8299.

Lundberg, M. and L. Squire (2003) 'The simultaneous evolution of growth and inequality', Economic Journal, 113, 326-44.

Lustig, N., L.F. Lopez-Calva and E. Ortiz-Juarez (2011) 'The decline in inequality in Latin America: How much, since when and why', ECINEQ Working Paper Series, No. 2011-211.

Maia, K. (2001) 'The impact of trade, technology and final demand on the structure of employment in Brazil, 1985-1995', Proceedings of the Workshop on Trade Liberalization and the Labor Market in Brazil, (Brasília, UnB/IPEA).

Márquez, G. and C. Pagés (1997) 'Trade and employment: evidence from Latin America and Caribbean', Inter-American Development Bank, Mimeo.

Meschi, E. and M. Vivarelli (2009) 'Trade and Income Inequality in Developing Countries', World Development, 37(2), 287-302.

O'Conner, D. and M. Lunati (1999) 'Economic opening and the demand for skills in developing countries: A review of theory and evidence', Technical Paper No.99/6, OECD Development Centre.

OECD (2011), Divided We Stand: Why Inequality Keeps Rising, OECD Publishing, http://dx.doi.org/10.1787/9789264119536-en;

Ortiz, I. and M. Cummins (2011) 'Global Inequality: Beyond the Bottom Billion. A Rapid Review of Income Distribution in 141 Countries', UNICEF Social and economic Policy Working Paper, April.

Pissarides, C. (1997) 'Learning by trading and the returns to human capital in developing countries', World Bank Economic Review, 11(1), 17-32.

Pomeranz, K. (2000), The Great Divergence, (Princeton, Princeton U.P).

Pritchett, L. (1997), 'Divergence, Big Time', Journal of Economic Perspectives, 11, 3, 3-17.

Rama, M. (2003) 'Globalisation and workers in developing countries', Policy Research Working Paper 2958, World Bank.

Ravallion, M. (2001) 'Growth, inequality and poverty: Looking beyond averages', World Development, 29(11), 1803-15.

Robbins, D. J. (1996) 'Evidence on trade and wages in the developing world', Technical Paper OECD Development Centre, No. 119.

Robbins, D.J. and T.H. Gindling (1999) 'Trade Liberalization and the Relative Wages for moreSkilled workers in Costa Rica', Review of Development Economics, 3, 140-154.

Solt, F. (2009), 'Standardizing the World Income Inequality Database', Social Science Quarterly, 90(2), 231-42. Available at:

http://dvn.iq.harvard.edu/dvn/dv/fsolt/faces/study/StudyPage.xhtml?studyId=36908\&versionNumber=3

Te Velde, D.W. (2003) 'Foreign direct investment and income inequality in Latin America: xperiences and Policy Implications', London: Overseas Development Institute.

Te Velde, D.W. and O. Morrissey (2004) 'Foreign direct investment, skills and wage inequality in East Asia', Journal of the Asia Pacific Economy, 9(3), 348-69.

Thurlow, J. (2006) 'Has trade liberalization in South Africa affected men and women differently?', International Food Policy Research Institute, Development Strategy and Governance Division, DSGD Discussion Paper, No. 36. Washington, DC, IFPRI.

Topalova, P. (2005) 'Trade liberalization, poverty and inequality: Evidence from Indian districts', NBER Working Paper, No. 11614. Cambridge, MA, National Bureau of Economic Research.

White, H. and E. Anderson (2001) 'Growth versus distribution: Does the pattern of growth matter?', Development Policy Review, 16(3), 267-89.

Wood, A. (1994) North-South Trade, Employment and Inequality. Changing Fortunes in Skill-Driven World, Oxford: Clarendon Press. 
Wood, A. (1997), Openness and Wage Inequality in Developing Countries, The Latin American Challenge to East Asian Conventional Wisdom, World Bank Research Observer, January, 33-57.

Wood, A. (1999) 'Openness and Wage Inequality in Developing Countries: The Latin American Challenge to East Asian Conventional Wisdom' in: R.E. Baldwin, D. Cohen, A. Sapir and A. Venables (eds.) Market Integration, Regionalism and Global the Economy (Cambridge, Cambridge University Press).

Wood, A. (2002) 'Globalisation and wage inequalities: A synthesis of three theories', Weltwirtschaftliches Archiv, 138(1), 54-82.

Zhang, X., J. Yang and S. Wang (2011) 'China has reached the Lewis turning point', China Economic Review, 22(4), 542-54.

Zin, R.H.M. (2005) 'Income Distribution in East Asian Developing Countries: recent trends', AsianPacific Economic Literature, 19(2), 36-54.

1 Asian NICs comprise Hong Kong, Korea, Singapore, Taiwan, Malaysia, Thailand, Indonesia and the Philippines.

${ }^{2}$ The differences between the trend for all households and the trends for rural and urban households result from (i) the moves in between-group (rural/urban) inequality and (ii) the changes in the weights of rural and urban households in the population.

${ }^{3}$ Typically measured by the real income per capita.

${ }^{4}$ See the special issue of the China Economic Review, 22(4), 2011

${ }^{5}$ The institutional variable is a composite measure obtained from the Political Risk Services' Country Risk Guide (2006). It is rated from 0 to 100 and made up of three measures: political, financial, and economic risk. 


\section{Documents de travail récents}

- Nathalie Chusseau and Michel Dumont: "Growing Income Inequalities in Advanced" [2012-24]

- Kirill Borissov and Stéphane Lambrecht : "The dynamics of income inequality in a growthmodel with human capital and occupational choice" [2012-23]

- Thomas Baudin: "More on Religion and Fertility: The French Connection" [2012-22]

- Thomas Baudin, David de la Croix and Paula Gobbi: "DINKs, DEWKs \& Co. Marriage, Fertility and Childlessness in the United States" [2012-21]

- Hamza Bennani: "National influences inside the ECB: an assessment from central bankers' statements" [2012-20]

- Marion Drut : "Vers un système de transport opérant selon les principes de l'économie de la fonctionnalité" [2012-19]

- Jean-François Fagnart et Marc Germain: "Macroéconomie du court terme et politique climatique: Quelques leçons d'un modèle d'offre et demande globales" [2012-18]

- Rodrigue Mendez: "Predatory Lending” [2012-17]

- Christophe Ley, Yvik Swan and Thomas Verdebout: "Optimal tests for the twosample spherical location problem" [2012-16]

- Jean-Philippe Garnier: "Social status, a new source of fluctuations?" [2012-15]

- Jean-Philippe Garnier: "Sunspots, cycles and adjustment costs in the twosectors model"[2012-14]

- François Langot, Lise Patureau and Thepthida Sopraseuth: "Optimal Fiscal Devaluation" [2012-13]

- Marc Germain: "Equilibres et effondrement dans le cadre d'un cycle naturel" [2012-12]

- Marc Hallin, Davy Paindaveine and Thomas Verdebout: "Optimal Rank-based Tests for Common Principal Components" [2012-11]

- Carlotta Balestra, Thierry Bréchet and Stéphane Lambrecht : "Property rights with biological spillovers: when Hardin meets Meade " [2012-10]

- Kirill Borissov, Thierry Bréchet, Stéphane Lambrecht: "Environmental Maintenance in a dynamic model with Heterogenous Agents" [2012-9] 